\title{
PRODUKSI TOTAL REACTIVE OXYGEN SPECIES PADA KULTUR JARINGAN MOLA HYDATIDOSA KOMPLIT DENGAN PEMAPARAN 17-BETA ESTRADIOL
}

\author{
Subandi Reksohusodo*® ${ }^{\star}$, Tatit Nurseta*
}

\begin{abstract}
Abstrak
Frekuensi kejadian mola hydatidosa yang berpotensi menjadi penyakit trofoblast ganas terus meningkat. Mekanisme patologis yang mendasari penyakit tersebut belum dapat dieksplorasi secara mendalam, terdapat pemikiran bahwa mekanismenya terkait dengan kerusakan oksidatif yang berhubungan dengan produksi reactive oxygen species (ROS). Diketahui bahwa hormon estrogen dan metabolitnya dapat memproduksi ROS, untuk itu perlu dianalisis seberapa jauh keterlibatan estrogen (17ßestradiol) dalam patomekanisme penyakit ini melalui pengukuran total ROS. Penelitian ini dilaksanakan secara eksperimental dengan menggunakan randomized group control design. Rancangan percobaan yang digunakan adalah rancangan acak lengkap dengan 1 kelompok perlakuan, yaitu kelompok kultur jaringan mola hydatidosa yang mendapat suplementasi estrogen (17ß-estradiol) dalam 4 dosis $(5 \mu \mathrm{g} / \mathrm{ml}, 10$ $\mu \mathrm{g} / \mathrm{ml}, 20 \mu \mathrm{g} / \mathrm{ml}, 40 \mu \mathrm{g} / \mathrm{ml}$ ) dan tanpa suplementasi. Dari hasil penelitian didapatkan perbedaan sangat bermakna kadar ROS antara kelompok kontrol dengan kelompok $17 \beta$-estradiol $5 \mu \mathrm{g} / \mathrm{ml}$ dan $17 \beta$-estradiol $40 \mu \mathrm{g} / \mathrm{ml}(p=0,000<0,05)$, antara kelompok perlakuan $17 \beta$-estradiol $10 \mu \mathrm{g} / \mathrm{ml}$ dan $17 \beta$-estradiol $40 \mu \mathrm{g} / \mathrm{ml}$ $(p=0,000<0,05)$ dan antara kelompok perlakuan $17 \beta$-estradiol $20 \mu \mathrm{g} / \mathrm{ml}$ dan kelompok perlakuan $17 \beta$ estradiol $40 \mu \mathrm{g} / \mathrm{ml}(\mathrm{p}=0,000<0,05)$. Disimpulkan bahwa pemberian $17 \beta$-estradiol $20 \mu \mathrm{g} / \mathrm{ml} \mathrm{dan} 40 \mu \mathrm{g} / \mathrm{ml}$ mempengaruhi produksi total ROS pada kultur jaringan mola hydatidosa.
\end{abstract}

Kata kunci: 17ß-estradiol, mola hydatidosa, reactive oxygen species (ROS).

\section{TOTAL PRODUCTION OF REACTIVE OXYGEN SPECIES IN COMPLETE HYDATIDIFORM MOLE'S TISSUE CULTURE WITH EXPOSURE OF 17-BETA ESTRADIOL}

\begin{abstract}
The frequency of hydatidiform mole (molar pregnancy) that developed into malignant trophoblast disease continues to increase. The pathological mechanisms are still unknown, but there is a thought that this mechanism is related to oxidative damage associated with the production of reactive oxygen species (ROS). Hormone estrogen and its metabolites can produce ROS. It is necessary to analyze how far estrogen involvement (17ß-estradiol) in the patho-mechanism of the disease through the measurement of the total ROS. The study was carried out experimentally by using a randomized control group design. The experimental design used was a completely randomized design (CRD) with a treatment group, that was hydatidiform mole culture which supplemented with estrogen (17ß-estradiol) in 4 doses $(5 \mu \mathrm{g} / \mathrm{ml}, 10 \mu \mathrm{g} / \mathrm{ml}$, $20 \mu \mathrm{g} / \mathrm{ml}, 40 \mu \mathrm{g} / \mathrm{ml}$ ) and those without supplementation. In this study, there were highly significant differences in ROS levels between control and treatment groups with $17 \beta$-estradiol $5 \mu \mathrm{g} / \mathrm{ml}$, and $17 \beta$ estradiol $40 \mu \mathrm{g} / \mathrm{ml}(p=0.000<0.05)$, between treatment groups of $17 \beta$-estradiol $10 \mu \mathrm{g} / \mathrm{ml}$ and $17 \beta$-estradiol $40 \mu \mathrm{g} / \mathrm{ml}(p=0.000<0.05)$ and between treatment groups of $17 \beta$-estradiol $20 \mu \mathrm{g} / \mathrm{ml}$ and $17 \beta$-estradiol $40 \mu$ $\mathrm{g} / \mathrm{ml}(p=0.000<0.05)$. It can be concluded that supplementation of $17 \beta$-estradiol $20 \mu \mathrm{g} / \mathrm{ml}$ and $40 \mu \mathrm{g} / \mathrm{ml}$ affects the production of total ROS in hydatidiform mole culture.
\end{abstract}

Keywords: 17ß-Estradiol, hydatidiform mole, reactive oxygen species (ROS).

* Divisi Onkologi, Bagian Obstetri dan Ginekologi, Fakultas Kedokteran, Universitas BrawijayaRS Universitas Brawijaya

区-mail: desobg@gmail.com 


\section{Pendahuluan}

Penyakit trofoblastik gestasional (gestational trophoblastic disease/GTD) merupakan kelompok penyakit yang muncul dari jaringan trofoblastik plasenta setelah fertilisasi normal maupun abnormal. ${ }^{1}$ WHO mengklasifikasikan GTD menjadi mola hydatidosa (komplit dan parsial), mola invasif, koriokarsinoma, tumor trofoblastik pada plasental site, miscellaneous dan lesi trofoblastik yang tidak terklasifikasi. ${ }^{2}$ Complete hydatidiform mole (CHM) merupakan varian yang jarang ditemui dan merupakan lesi plasenta yang ditandai dengan villi khorionik yang melebar, edematous, dan vesikuler, disertai proliferasi trofoblastik pada berbagai derajat. $^{3}$

Terdapat variasi distribusi GTD yang luas di seluruh dunia, dengan frekuensi lebih tinggi didapatkan di beberapa bagian Asia, Timur Tengah, dan Afrika. Tingkat kejadian GTD adalah $130 \pm 10$ kasus per 100.000 kehamilan, yang diklasifikasikan sebagai lalat hydatidiform (HM), lalat invasif, atau neoplasma ganas plasenta dengan tingkat kejadian masing-masing $110 \pm 10,20 \pm 0$, atau $10 \pm 0$ kasus per 100.000 kehamilan. Insiden GTD terendah di antara wanita berusia akhir 20-an dan awal 30-an. Kejadian HM menyumbang $80,3 \%$ semua kasus GTD. 4

Sebagian besar penderita mola hidatidosa akan menjadi baik kembali setelah ditangani secara tuntas. Tetapi lebih kurang $15-20 \%$ akan mengalami transformasi keganasan menjadi tumor trofoblas gestasional (TTG). 5

Reactive oxygen species diproduksi selama proses metabolik dan fisiologis normal. Namun, pada kondisi tertentu, peningkatan oksidan dan penurunan antioksidan tidak dapat dicegah, sehingga keseimbangan oksidan/antioksidan bergeser pada kondisi oksidatif. Sebagai konsekuensi, terbentuklah stres oksidatif yang terlibat pada banyak kondisi patologis. ${ }^{6}$ Terganggunya keseimbangan oksidan/antioksidan diperkirakan merupakan faktor penyebab yang mendasari kerusakan oksidatif terhadap molekul seluler seperti DNA. ${ }^{7}$

Sel-sel di dalam tubuh kita berada dalam keseimbangan. Keseimbangan antara proliferasi, diferensiasi dan apoptosis dari sel merupakan salah satu pengatur utama perilaku tumorigenik atau kemampuan invasif tumorigenik pada trofoblas. Mekanisme patologis yang mendasari penyakit trofoblastik gestasional belum dieksplorasi secara luas, namun terdapat pemikiran bahwa mekanisme ini terkait dengan kerusakan oksidatif yang berhubungan dengan produksi ROS. Produksi ROS bisa dideteksi berdasarkan sumber asal ROS dihasilkan. Pada ROS yang dihasilkan oleh reaksi peroksidasi lemak, dapat dideteksi dengan melihat kadar senyawa malondialdehida menggunakan tes thiobarbituric acid reactive substances (TBARS). Selain itu, deteksi produksi ROS dapat menggunakan probe hidroetidin (HE) yang merupakan probe fluorogenik yang paling banyak digunakan untuk deteksi anion radikal superoksida intraseluler. ${ }^{8}$

Penyakit keganasan trofoblas (Tumor Trophoblas Gestasional) dapat menimbulkan gejala klinik ringan sampai berat yang dapat mengakibatkan kematian. ${ }^{9}$ Gejala klinik yang ditimbulkan tergantung dari daya invasif tumor dan kemampuan metastasisnya. Sehingga deteksi dini dan penanganan yang tepat diperlukan untuk pengobatan penyakit ini. ${ }^{10}$ Upaya pencegahan penyakit trofoblas mola menjadi ganas sangat diperlukan mengingat bahaya yang ditimbulkanya, tetapi sampai saat ini patofisiologi masih belum jelas dan sangat sedikit penelitian yang telah dilakukan. ${ }^{11}$

Untuk melakukan penelitian sel trofoblas mola tidak mungkin dilakukan pada manusia. Oleh karena itu dibutuhkan media kultur sel trofoblas secara in vitro yang menyerupai kondisi sebenarnya sehingga dapat diberikan berbagai perlakuan yang diinginkan. 
Oleh karena itu, perlu dilakukan penelitian eksperimental mengenai efek estrogen (17 $\beta$ estradiol) terhadap produksi total ROS pada kultur jaringan mola hydatidosa.

\section{Bahan dan Metode}

\section{Desain Penelitian}

Penelitian ini dilaksanakan secara eksperimental menggunakan randomized group control design. Rancangan percobaan yang digunakan adalah Rancangan Acak Lengkap (RAL) dengan 1 kelompok perlakuan, yaitu kelompok kultur jaringan mola hydatidosa yang mendapat suplementasi estrogen (17 $\beta$-estradiol) berbagai dosis dan tanpa suplementasi.

\section{Subjek Penelitian}

Penelitian ini menggunakan sampel jaringan mola hydatidosa dari hasil suction curretage mola hydatidosa. Penelitian ini telah mendapatkan persetujuan etik dari Komite Etik Penelitian Kesehatan, Fakultas Kedokteran, Universitas Brawijaya dengan nomor 132/KEPK-FKUB/05/2012.

\section{Isolasi dan Kultur Jaringan Mola Hydatidosa}

Prosedur kultur jaringan mola hydatidosa dilakukan di Laboratorium Faal, Fakultas Kedokteran, Universitas Brawijaya. Jaringan mola hydatidosa hasil suction curretage dicuci dengan normal salin, gelembung mola lalu dimasukkan ke dalam larutan cord solution (Hank's balance salt solution (Sigma H 1641), gentamycine (Gentamerck), sodium hydrogen bicarbonate (Sigma), phenol red (Sigma P5530), HEPES solution (Sigma), and deionized water (WFI Otsuka) dan disimpan ke refrigerator. Pengerjaan kultur jaringan mola hydatidossa tidak melebihi 12 jam setelah waktu pengambilan sampel, dilakukan pemilihan gelembung mola dari jaringan mola hydatidosa, dan selanjutnya dikultur. Gelembung mola diinkubasi dalam larutan
Collagenase (type 1) $7 \mathrm{mg} / 10 \mathrm{cc}$ selama 2 jam, dan disentrifus pada 2,000 rpm selama 7 menit. Supernatan dibuang dan pelet diresuspensi ke dalam serum free media. Kemudian disentrifus kembali dan pelet diresuspensi ke dalam $4 \mathrm{~mL}$ medium kultur yang mengandung newborn calf serum (NCS, [Sigma N4637]) and 10\% FBS, lalu diinkubasi di inkubator $37{ }^{\circ} \mathrm{C}, 5 \% \mathrm{CO}_{2}$. Kultur diamati menggunakan mikroskop.

Kultur Jaringan mola dibagi ke dalam 5 kelompok; Kelompok I: tanpa ditambahkan estrogen (17ß-estradiol), kelompok II: ditambahkan estrogen dosis fisiologis $(10 \mu \mathrm{g} /$ ml 17ß-estradiol), kelompok III: ditambahkan estrogen dosis rendah $(5 \mu \mathrm{g} / \mathrm{ml}$ 17ßestradiol), kelompok IV: ditambahkan estrogen dosis sedang $(20 \mu \mathrm{g} / \mathrm{ml}$ 17 $\beta$ estradiol), kelompok $\mathrm{V}$ : ditambahkan estrogen dosis tinggi $(40 \mu \mathrm{g} / \mathrm{ml} \quad 17 \beta$ estradiol).

\section{Reactive Oxygen Species (ROS) Assay}

Pengukuran kadar ROS dari medium kultur menggunakan Colorimetric Hidrogen Peroxide Kit (Assay Design). Larutan standart dibuat dengan melarutkan $34 \mu \mathrm{l}$ stok Hydrogen Peroxide Standart dengan $966 \mu \mathrm{l}$ diluent dan disebut sebagai larutan standart I. Larutan standart II dibuat dengan melarutkan $500 \mu \mathrm{l}$ larutan standart I dengan $500 \mu \mathrm{l}$ diluent. Dibuat hingga larutan standart 6 dengan cara yang sama. Kemudian dimasukkan $50 \mu$ diluent pada well 1 sebagai larutan blanko, $50 \mu \mathrm{l}$ larutan standart 1 hingga IV ke dalam well selanjutnya. Masingmasing larutan sampel dia mbil $50 \mu \mathrm{l}$ dimasukkan ke dalam well selanjutnya. Selanjutnya semua well ditambahkan $100 \mu \mathrm{l}$ Color Reagent dan dipipeting selama 1 detik. Inkubasi dilakukan pada suhu ruang selama 30 menit. Selanjutnya dibaca pada panjang gelombang $550 \mathrm{~nm}$ dengan Elisa Reader. Angka hasil bacaan Colorimeter yang berbanding terbalik dengan intensitas warna senyawa hasil reaksi $\mathrm{H}_{2} \mathrm{O}_{2}$ 
dalam supernatan kultur sel dengan reagen yang mengandung besi dan pewarna xylenol yang menghasilkan warna ungu, dimana intensitas warna ungu ini sebanding dengan kadar $\mathrm{H}_{2} \mathrm{O}_{2}$ dalam supernatan kultur tersebut.

\section{Analisis Data}

Data disajikan dengan delta rata-rata produksi total ROS pada kultur jaringan mola hydatidosa, perbedaan antar kelompok dianalisis menggunakan one-way ANOVA dan post hoc dengan SPSS 15.

\section{Hasil}

Pada Gambar 1 dapat dilihat produksi total ROS pada kelompok kontrol dan kelompok perlakuan. Peningkatan produksi total ROS diketahui sesuai dengan peningkatan dosis 17ß-estradiol yang diberikan dan didapatkan tertinggi pada kelompok V (40 mg/ml 17ß-estradiol).

Hasil analisis uji ANOVA menunjukkan bahwa produksi ROS pada kultur jaringan mola hydatidosa menunjukkan adanya perbedaan yang signifikan antara kelompok kontrol dengan kelompok 17ß-estradiol $5 \mu \mathrm{g} /$ $\mathrm{ml}$ dan $17 \beta$-estradiol $40 \mu \mathrm{g} / \mathrm{ml}(p=0,000<$ $0,05)$, antara kelompok perlakuan 17 $\beta$ estradiol $10 \mu \mathrm{g} / \mathrm{ml}$ dan $17 \beta$-estradiol $40 \mu \mathrm{g} / \mathrm{ml}$ $(p=0,000<0,05)$ dan antara kelompok perlakuan 17ß-estradiol $20 \mu \mathrm{g} / \mathrm{ml}$ dan kelompok perlakuan $17 \beta$-estradiol $40 \mu \mathrm{g} / \mathrm{ml}(\mathrm{p}$ $=0,000<0,05$ ). Selain itu, didapatkan selisih rata-rata antara setiap kolompok perlakuan yang diuji dalam penelitian ini berbeda cukup banyak, sehingga secara statistik perbedaan yang ada bersifat signifikan.

\section{Produksi Total ROS pada Kultur Jaringan Mola Hydatidosa}

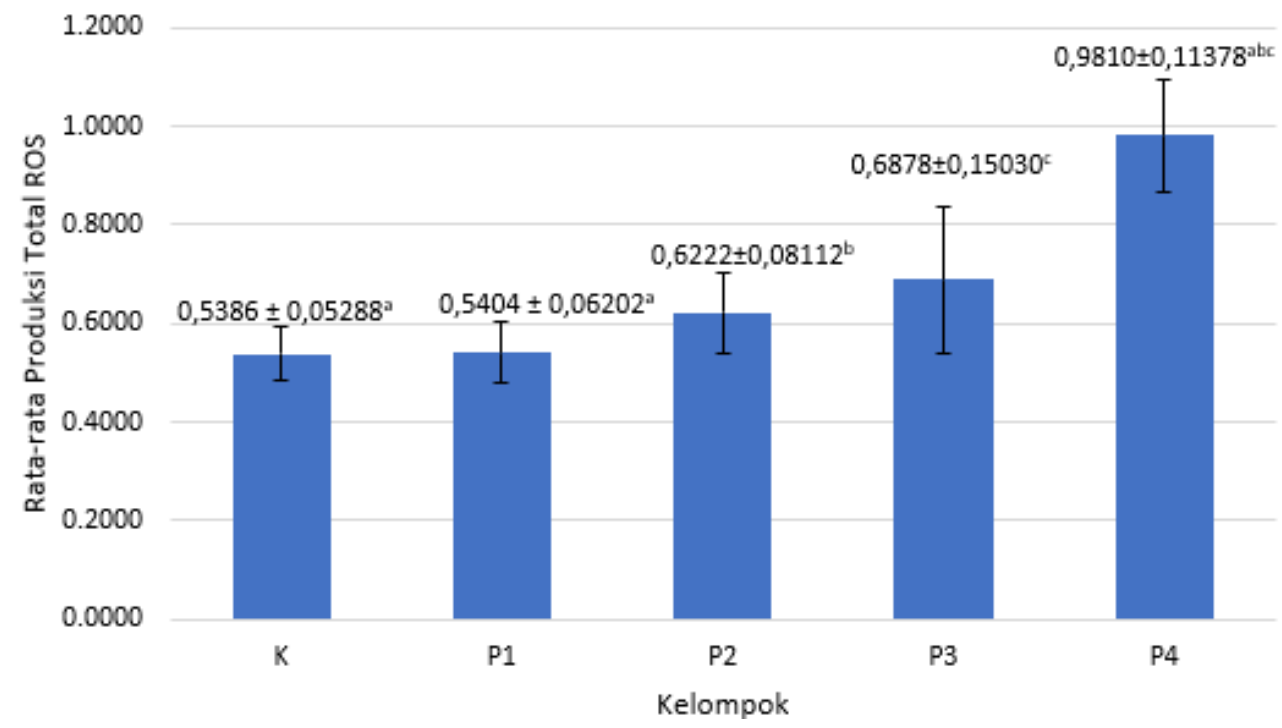

Gambar 1. Produksi total ROS pada kultur jaringan mola hydatidosa.

Keterangan: K: Kontrol, P1: $17 \beta$ estradiol $5 \mu \mathrm{g} / \mathrm{ml}$, P2: $17 \beta$ estradiol $10 \mu \mathrm{g} / \mathrm{ml}, \mathrm{P} 3: 17 \beta$ estradiol $20 \mu \mathrm{g} / \mathrm{ml}$, P4: $17 \beta$ estradiol $40 \mu \mathrm{g} / \mathrm{ml}$. Notasi a: $p<0,05$ dibandingkan $\mathrm{K}$, notasi $\mathrm{b}: \mathrm{p}<0,05 \mathrm{P} 2$ dibandingkan $\mathrm{P} 4$, notasi $c ; \mathrm{p}<0,05 \mathrm{P} 3$ dibandingkan $\mathrm{P} 4$. 


\section{Pembahasan}

Pada penelitian ini, produksi ROS pada kultur jaringan mola hidatidosa yang diberikan 17ß-estradiol $5 \mu \mathrm{g} / \mathrm{ml}$ dan $10 \mu \mathrm{g} / \mathrm{ml}$ tidak menunjukkan perbedaan yang bermakna (tidak signifikan) dibandingkan dengan kelompok kontrol. Hal ini disebabkan dosis 5 $\mu \mathrm{g} / \mathrm{ml}$ dan $10 \mu \mathrm{g} / \mathrm{ml}$ merupakan dosis rendah dan secara fisiologis tidak mempengaruhi produksi ROS. Kemudian produksi ROS pada kultur jaringan mola hydatidosa kembali meningkat ketika diberikan 17ß- estradiol yang lebih tinggi yaitu dosis $20 \mu \mathrm{g} / \mathrm{ml}$ dan 40 $\mu \mathrm{g} / \mathrm{ml}$. Bahkan pada dosis $40 \mu \mathrm{g} / \mathrm{ml}$ dapat menunjukkan produksi ROS pada kultur jaringan mola hydatidosa yang paling tinggi.

Sel trofoblas normal maupun yang patologis secara histologi sama yaitu menunjukkan ekspresi reseptor estrogen. ${ }^{12}$ Pada sel trofoblas mola terdapat ekspresi reseptor estrogen alfa (ER- $\alpha$ ) yang berada di villous sitotrofoblas (CT). Selain itu, dengan analisis Western blot diketahui terdapat reseptor estrogen beta (ER- $\beta$ ) pada chorionic vili (CV) terbatas hanya pada sinsitiotrofoblas. ${ }^{13}$ Senyawa $17 \beta$-estradiol yang berperan sebagai hormon estrogen bisa masuk melalui membran plasma dan berinteraksi dengan ER $\alpha$ dan ER $\beta$ intraseluler untuk memberikan efek langsung melalui ikatannya dengan sekuen DNA. Namun, estrogen juga bisa mengaktifkan kaskade signal intraseluler via GPER1 dan/ atau ER $\alpha$ dan ER $\beta$. Terkait dengan hal ini, peristiwa signaling yang diperantarai oleh estrogen dibagi menjadi genomik dan nongenomik. Efek genomik yaitu melibatkan kompleks estrogen-reseptor ke dalam inti sel dan interaksinya secara langsung dengan kromatin pada sekuen estrogen response elements (EREs). Sementara itu, efek nongenomik melibatkan regulasi ekspresi gen melalui berbagai peristiwa signaling intraseluler. ${ }^{13}$
Estrogen alami seperti $17 \beta$-estradiol dan estrone dapat membentuk cathecol estrogen melalui aktivitas gen CYP1A1, CYP1A2 dan CYP1B1. Cathecol estrogen berfungsi sebagai molekul signaling, namun demikian juga menghasilkan senyawa genotoksik pemicu karsinogenesis yang menyebabkan ikatan yang tidak stabil dengan adenin dan guanin pada DNA dan menyebabkan depurinasi dan mutasi in vitro maupun in vivo. Proses reduksi estrogen quinon menjadi hydroquinon dan catechol menyebabkan produksi reactive oxygen species yang menyebabkan kerusakan oksidatif pada lipid dan DNA akibat paparan estrogen. .4, $^{4}$

Oleh karena itu, berdasarkan nilai ratarata produksi ROS pada kultur jaringan mola hydatidosa, bahwa $17 \beta$-estradiol memberikan pengaruh yang berbeda dalam meningkatkan produksi ROS pada kultur jaringan mola hydatidosa jika dibandingkan dengan kelompok kontrol.

\section{Kesimpulan}

Produksi total ROS pada kultur jaringan mola hydatidosa yang dipapar dengan $17 \beta$ estradiol dosis $20 \mu \mathrm{g} / \mathrm{ml}$ dan $40 \mu \mathrm{g} / \mathrm{ml}$ menunjukkan adanya perbedaan yang signifikan $(p<0.05)$ dibandingkan dengan $17 \beta$ estradiol dosis $5 \mu \mathrm{g} / \mathrm{ml}$ dan $10 \mu \mathrm{g} / \mathrm{ml}$, dan kelompok kontrol.

\section{Daftar Pustaka}

1. Ning $F$, Hou $H$, Morse AN, Lash GE. Understanding and Management of Gestational Trophoblastic Disease [version 1; peer review: 2 approved]. [Internet]. F1000Research 2019; 8(F1000 Faculty Rev):428. [cited 2020 Sep 29]. Available from: /pmc/articles/ PMC6464061/?report=abstract. 
2. Ngan HYS, Seckl MJ, Berkowitz RS, Xiang $\mathrm{Y}$, Golfier F, Sekharan PK, et al. Update on the Diagnosis and Management of Gestational Trophoblastic Disease. Int J Gynecol Obstet. 2018; 143:79-85. DOl: http:// doi.wiley.com/10.1002/ijgo.12615.

3. Carey L, Nash BM, Wright DC. Molecular Genetic Studies of Complete Hydatidiform Moles. Transl Pediatr. 2015; 4(2):181.

4. Yuk JS, Baek JC, Park JE, Jo HC, Park JK, Cho IA. Incidence of Gestational Trophoblastic Disease in South Korea: A longitudinal, Population-Based Study. Peer J. 2019; 2019(2). e6490. doi: 10.7717/peerj.6490. eCollection 2019.

5. Huang $F$, Zheng $W$, Liang $Q$, Yin $T$. Diagnosis and Treatment of Placental Site Trophoblastic Tumor. Int J Clin Exp Pathol. 2013; 6(7):1448-51. Available from: www.ijcep.com/.

6. Pambuk CIA and Muhammad FM. Free Radicals: The Types Generated in Biological System. MOJ Cell Sci Rep. 2018; 5(3):72-73. DOI: 10.15406/ mojcsr.2018.05.00118.

7. Lee $\mathrm{T}-\mathrm{H}$, Kang T-H. DNA Oxidation and Excision Repair Pathways. Int. J. Mol. Sci. 2019; 20(23):6092. https:// doi.org/10.3390/jims20236092.

8. Çakmak B, Toprak M, Nacar MC, Köseoğlu RD, Güneri N. Incidence of Gestational Trophoblastic Disease In Tokat Province, Turkey. J Turkish Ger Gynecol Assoc. 2014; 15(1):22-4.

9. De Nola $R$, Schönauer LM, Fiore MG, Loverro M, Carriero C, Di Naro $E$. Management of Placental Site
Trophoblastic Tumor. Medicine. 2018; 97 (48):e13439.

10. Braga A, Mora P, Melo AC de, NogueiraRodrigues A, Amim-Junior J, RezendeFilho J, et al. Challenges in the Diagnosis and Treatment of Gestational Trophoblastic Neoplasia Worldwide. World J Clin Oncol. 2019; 10(2):28-37.

11.Lurain JR. Gestational Trophoblastic Disease I: Epidemiology, Pathology, Clinical Presentation and Diagnosis of Gestational Trophoblastic Disease, and Management of Hydatidiform Mole. American Journal of Obstetrics and Gynecology. 2010; 203(6):531-9. DOI:https://doi.org/10.1016/ j.ajog.2010.06.073.

12. Snijders $M$, Theunissen $P$, Debets-Te Baerts Koudstaal M J. Immunhistochemischer Nachweis von Ostrogen- und Progesteronrezeptoren In Paraffinschnitten. Pathologe. 1990; 11:236 $-9$.

13. O'Lone R, Frith MC, Karlsson EK, \& Hansen U. Genomic Targets of Nuclear Estrogen Receptors. Mol Endocrinol. 2004; 18(8):1859-1875.

14.StraussIII JF, FitzGerald GA. Streroid Hormone and Other Lipid Molecules Involved in Human Reproduction. In Yen and Jaffe's Reproductive Endrocrinology. Physiology, Pathophysiology, and Clinical Management. $8^{\text {th }}$ Edition. 2019. P. 75114.e7.

15. Boon WC, Chow JDY, Simpson ER. The Multiple Roles of Estrogens and the Enzyme Aromatase. Prog Brain Res. 2010; 181(C):209-32. 